\title{
Teacher's Expressive Speech Acts in Learning Bahasa Indonesia Class XI at SMA 1 Luhak Nan Duo
}

\author{
Ermawati Arief ${ }^{1, *}$ Tressyalina $^{1}$ Ena Noveria ${ }^{1}$ \\ ${ }^{1}$ Indonesian Language and Literature, Universitas Negeri Padang, Padang, Indonesia \\ *Corresponding author. Email: ermawatiarief1962@ gmail.com
}

\begin{abstract}
The objectives of this study are threefold. First, describe the forms of expressive speech acts used by Indonesian language teachers in the teaching and learning process in class XI SMA Luhak Nan Duo. Second, describe the strategies of the Indonesian language teachers in the teaching and learning process in class XI SMA 1 Luhak Nan Duo. The data in this study were sentences in the form of expressive speech act forms and strategies for the Indonesian language teacher class XI SMA 1 Luhak Nan Duo in the teaching and learning process. The data source of this research is the entire utterances of an Indonesian language teacher during the teaching and learning process from the beginning to the end of the lesson. The research instrument is the author himself. The results of this study are twofold. First, there are five forms of expressive speech acts of teachers in learning Indonesian language at SMA N 1 Luhak Nan Duo, (1) expressive speech acts praising, (2) expressive speech acts saying thank you, (3) expressive speech acts criticizing, (4) blaming expressive speech acts, and (5) expressive speech acts of apologizing. Second, there are four teacher speaking strategies in learning Indonesian for class XI in high school, (1) the strategy to speak frankly without further ado, (2) the strategy to speak frankly with positive politeness, (3) the strategy to speak candidly with negative politeness pleasantries, and (4) obscure narrative strategies. (4) blaming expressive speech acts, and (5) expressive speech acts apologizing.
\end{abstract}

Keywords: expressive, strategies, speech act

\section{INTRODUCTION}

The role of the teacher as a speaker is very important in the implementation of teaching and learning in the classroom. This is the main key in the speech acts performed by the teacher. The teacher is an input or learning resource for students, both when delivering material or guiding students in activities. So that in the end there will be fun teaching and learning activities in the classroom. Speech acts that have an important role in conveying something that are felt by the speakers are called expressive speech acts.

The expressive speech acts used by the teacher are intended as a means of educating, guiding, and guiding students in the learning process. For example, expressions of praise to blame will be able to affect the student's own emotional. From this, the interaction between teachers and students is formed during the learning process. The reciprocal relationship that occurs aims to educate and guide students so that they can be focused not only in learning but also how they interact with the social environment and other individuals. This also cannot be separated from the teacher's ability to choose speech strategies when performing speech acts to students.

The storytelling strategy must be considered by the teacher in order to get good and courteous responses from students so that there is mutual communication in the teaching and learning process. If the speaking strategy used by the teacher is right on target, then the response from students will also be as expected by the teacher as a speaker. On the other hand, if the speech strategy used by the teacher is not correct, the response that the teacher will receive will be far from expectations, maybe even the teacher will not get a response from students during the teaching and learning process. This research is focused on the form of expressive speech acts and the teacher's speaking strategy in Indonesian language learning in class XI SMA 1 Luhak Nan Duo. 
Speech acts are all language and non-language components which include language actions that are intact and involve speakers and speech partners. According to Yule (2006: 82) speech acts are actions that are displayed through speech [1]. In line with that Chaer (2010: 27) argues that speech act are utterances from someone who is psychological in nature and seen from the meaning of actions in his speech [2]. Furthermore, Richard and Plat (in Abdurrahman, 2006: 127) state that a speech act is a speech or utterance which is a functional unit in communication [3].

The research speech acts will focus on expressive speech acts. According to Searle (in Rahardi, 2003: 73), expressive speech is a form of speech that is intended to express or show a speaker's psychological attitude towards a situation [4]. This speech is uttered with the intention that the utterance conveyed by the speaker to his interlocutor can be interpreted as an evaluation of what is mentioned in the utterance. Next, Rustono (1999:42) suggests that the forms of expressive speech acts include praising, thanking, criticizing, blaming congratulating, apologizing, and flattering [5].

The storytelling strategy is how or the technique used by speakers in delivering interesting speech by considering the speech situation. According to Halid, et al (2011: 2) teacher speech acts that do not threaten the face of students will motivate students to take part in the learning process so that students will be motivated to express their ideas in the classroom which in turn will create communicative communication between students and relationships [6]. teachers with students are more harmonious.

Furthermore, Brown and Levinson (in Syahrul, 2008: 18-19) divide the strategy of speaking into five parts, namely (1) the strategy to speak frankly without further ado (BTTB), (2) the strategy of speaking with positive politeness (BTDKP), (3) talk strategy with negative politeness (BTDKN), (4) vague speech strategy (BSS), and (5) silent speech strategy $(\mathrm{BDH})$ [7].

The objectives to be achieved in this study are as follows. First, describe the forms of expressive speech acts used by Indonesian language teachers in the teaching and learning process in class XI SMA 1 Luhak Nan Duo. Second, describe the strategies of the Indonesian language teachers in the teaching and learning process in class XI SMA 1 Luhak Nan Duo

\section{RESEARCH METHODS}

This type of research is qualitative research with descriptive methods. Descriptive method is a research method to create a picture of a process or event that occurs. This research is classified as a qualitative research because it aims to produce descriptive data in the form of teacher speeches in the Indonesian language learning process for class XI at SMA N 1 Luhak Nan Duo.

The data in this study are in the form of sentences and expressive speech act strategies of the Indonesian language teacher class XI SMA 1 Luhak Nan Duo in the teaching and learning process. The data source of this research is the entire utterances of an Indonesian language teacher during the teaching and learning process from beginning to end of learning.

The data collection technique used by the writer is passive participation observation. According to Stainback (in Sugiyono 2014: 227) states that passive participation observation makes the writer or researcher come to the place of research or the place of activity being observed but not involved in the activity [8]. Data collection was done by recording and recording. The author is only an observer and then records and records all speech acts and activities that occur in the place of activity. The data obtained from the recordings were then transcribed into written language. Furthermore, the data analysis technique carried out by the author. First, the data from the voice recordings are transcribed into written language. Second, identify expressive speech acts used by Indonesian language teachers and student responses during the teaching and learning process. Third, classify the data based on expressive speech acts and their speech strategies. Fourth, analyzing the data that has been previously obtained. Fifth, conclude the data based on the findings of the research and discussion.

\section{DISCUSSION}

Based on the findings of the research on expressive speech acts of teachers in learning Indonesian for class XI at SMA 1 Luhak Nan Duo, it was found that there were five forms of expressive speech acts and four speech strategies used. The form of expressive speech act that is mostly uttered by the teacher is the expressive speech act of praise. Then, the form of expressive speech act that was uttered the least by the teacher was the expressive speech act of apologizing. The following is a discussion of the teacher's expressive speech acts in learning Indonesian for class XI at SMA 1 Luhak Nan Duo. 


\subsection{Forms Of Expressive Speech Actions Used By Teachers In Learning Bahasa Indonesia Class XI At SMA 1 Luhak Nan Duo}

Based on the results of the data findings, in this study the authors found five forms of expressive speech acts used by teachers in learning Indonesian for class XI at SMA N 1 Luhak Nan Duo. The five forms of speech acts are praising, saying thank you, criticizing, blaming, and apologizing. This is in line with the opinion of Rustono (1999: 42) states that the form of expressive speech acts includes utterances of praise thanksgiving, criticism, blame, congratulations, apologize, and flatter.

The most dominant form of speech act uttered by the teacher is the speech act of praise. This is because the teacher's role as educators is to motivate and provide enthusiasm for learning to students in the teaching and learning process for the advancement of students' mindsets so as to create a good learning atmosphere. The teacher uses the form of praising speech act because he feels that what the teacher expects to his students is in accordance with his wishes. For example, students can answer questions raised by the teacher or the actions and attitudes of students during the learning process in class according to the expectations of the teacher who is teaching. There were 12 forms of expressive speech acts uttered by the teacher. The following is one of the findings of praising speech acts in learning.

(1) Well, that's it. Good, that's what Ananda can mean! (T26)

In the above speech, the teacher praises one of the students named Sintia. Praise is given because these students can answer questions from the teacher in their own language. According to Sari (2012: 7-11) praising is a speech act that occurs due to several factors due to the condition of the interlocutor in accordance with the existing reality, because the speaker wants to relieve the heart or seduce the interlocutor [9]. Here are other findings from praising speech acts.

(2) Yes, right! To agree. (T46)

The speech on the bag is also a form of praising expressive speech acts. There is a marker for the word "correct" which is uttered by the teacher to reaffirm that the answers from students are correct and in accordance with the teacher's expectations.

Furthermore, the speech uttered by the teacher is a form of expressive speech act of saying thank you. This form of speech act was found in only 5 utterances. Saying thank you is a form of speech used to express gratitude in order to return favor, kindness, or a feeling of satisfaction or pleasure about something. The form of speech that is quite widely spoken by the teacher, because being a teacher directly will also be a model that is observed and imitated by students regarding how the teacher behaves to others, asks for and receives help, and says thank you as a good response to someone for their actions and actions according to our will. This form of speech is capable of being self-development, character, and social skills if students can carry it out directed and continuously so as to create a culture of polite communication to respect each other. The following is one form of expressive speech act to say thank you.

\section{(3) Thank you. (T145)}

In the speech of gratitude above, the speech was expressed by the teacher when the students had finished reading the textbook requested by the teacher. The teacher poured out his satisfaction to the students with an expression of gratitude. The form of the speech above is in accordance with Sari's opinion (2012: 7-11) saying thank you is a speech act that usually occurs due to several factors, namely due to the 'praising' utterance spoken by the speaker to the interlocutor or because of the kindness of the interlocutor who has give something to the speaker. From the above opinion, it is known that the speech act fulfills the conditions for the kindness of the interlocutor to do the will of the speaker in exchange for the speaker's gratitude.ext, the speech uttered by the teacher is an expressive form of critical speech act. There were 10 speech acts criticizing the Indonesian language learning process. Teachers as guides and supervisors have a role to help, improve, and also critically assess the student learning process with input, responses, and criticism to limit what students do not have to do. In addition, criticism is also needed so that the direction of learning is in accordance with what has been designed and developed by the teacher, but does not give excessive burdens to students. Criticizing means giving criticism or response to a speech or delivering criticism about something that is lacking or inappropriate.

(4) Actually Ananda knows, but he is lazy to think! Yes? Cannot deliver, whereas yesterday an example was presented! (T129)

The above speech is a form of critical speech act. The teacher conveyed his response to the students in the form of criticism because the students in the local area 
were silent too much and there was a lack of reciprocal interaction with the teacher. According to Sari (2012: 7-11) criticizing is a speech act that occurs because the speaker does not like or disagree with what is done or said by the other person. Other examples are as follows.

(5) This is just Ririn's opinion, it doesn't match the material. So please fix it again! That's just one, I haven't finished checking again. Lasis continued, the fifth task, retelling the biographical text. (T97)

In the situation the speech above is also a critical form of expressive speech act. The teacher gave a response to one of the students' assignments that was still inaccurate. In accordance with the previous opinion that criticism occurs because of disagreement between teachers and students.

Furthermore, the speech uttered by the teacher is an expressive speech act of blaming. Blaming is a form of viewing or mistaking an activity, action, or speech from someone. Blaming speech uttered by the teacher in the learning process also aims to make students feel guilty so that students can immediately correct their mistakes. In the research findings, there were 11 blaming speech acts. Quite a number of forms of speech are due to the role of the teacher in encouraging students' thinking abilities so that they become attention again for the students themselves. The need for students to be able to develop thinking power in processing the material provided by the teacher so that students not only receive material but also can understand and express thoughts individually.

(6) If this is what Ririn answers its not structure! (T96)

The speech above is a form of blaming speech act uttered by the teacher. This is confirmed by the presence of the word "not" in the speech. The teacher considers that the answer to the assignment given by the student is wrong. Other examples are as follows.

(7) The answer is not like this! That structure you know? (T93)

The same thing is found in this speech. The existence of the word "not" also makes the utterance included in the form of an expressive speech act of blaming.

The last form of speech uttered by the teacher is the expressive speech act form of apologizing. Apologizing speech is the form of speech that is at least found in the Indonesian language learning process, namely there are only 2 utterances. This is related to the ability of teachers who must be able to try to avoid actions in the form of mistakes that will lower their self- esteem. Even so, teachers will also not be free from mistakes. Teachers must be able to position themselves as role models for their students. Based on the findings of the research, the mistakes made by the teacher in the form of speech acts were only a form of accident. The following is the form of the findings from the research results.

(8) Oh yeah, sorry. Task six huh. Task five just sums up. (T99)

In the above speech, it is clearly shown that the apology speech uttered by the teacher to students with a marker for the word "sorry". The teacher apologizes to students because the teacher misrepresents information related to the assignment to be done by the student. This can happen because of the corrections from students who feel awkward with the assignment given. Another form of speech act of apologizing is as follows.

(9) For example in chapter I. Sorry! The point is in paragraph one. (T101)

Likewise with this speech, it can be seen that there is a marker for the word "sorry" in the teacher's speech. However, in his speech, the teacher himself realized his mistake when explaining the learning material.

\subsection{Speaking Strategies Used by Teachers in Learning Bahasa Indonesia Class XI at SMA N 1 Luhak Nan Duo}

In previous research, only four types of speaking strategies were found in the expressive speech acts of teachers in Indonesian language learning for class XI at SMA 1 Luhak Nan Duo, namely (1) the strategy to speak frankly without further ado (BTTB), (2) ) the strategy of speaking with positive politeness (BTDKP), (3) the strategy of speaking with negative politeness (BTDKN), (4) the strategy of speaking vaguely (BSS).

The strategy that is most widely used is the talk strategy without further ado, there are as many as 21 speeches. The speaker directly expresses his intentions to the speech partner without having to think long enough to understand the intent of the speaker directly and without further ado. The strategy that is least used is the obscure strategy because the strategy is poorly understood by students. The vague speech strategy requires the speech partner to be able to understand for himself the meaning of the speech of the speaker. 


\subsubsection{Strategy to Speak Frankly Without Further Ado}

The strategy of speaking frankly without further ado was found as many as 21 utterances. This strategy is used to convey the intent of the teacher's speech in a straightforward manner and does not appear to be trivial. This strategy aims to make it easy for students to understand the meaning of the speech without the need for further explanation. The storytelling strategy most widely used by teachers is related to the teacher's role as a communicator, which is to train to develop students' comprehension skills. It also aims to make the learning process not seem wordy and waste time which can cause students to get bored easily and the situation becomes unpleasant for students. With this storytelling strategy, students can immediately understand without having to ask again the meaning of the teacher's speech. Like the following speech.

(1) Thank you. (T145)

The above speech is a form of expressive speech act of saying thank you. The teacher straightforwardly expressed gratitude to students without the need for further explanation. Direct students can easily understand these utterances because there is no impression of pleasantries in them.

\subsubsection{Strategy to Speak Frankly with Positive Politeness}

The strategy of speaking frankly with positive politeness was found as many as 9 utterances in the learning process. In the teaching and learning process, teachers are required to be able to build reciprocal relationships that can be followed well by students. The occurrence of this learning process is not only about providing knowledge, but also inculcating character values to students. This can be obtained by the existence of a psychological relationship initiated by the teacher to the students. Like how the teacher chooses a strategy to speak candidly with positive politeness, which can influence students to act and interact well and can even be used as a basis for students to behave. The following are the findings of the strategy research, telling frankly with positive politeness.

(2) Well, great! Like that answer it! That means Ananda can already answer the questions! (T34)

The above speech is a form of praising speech act with a strategy of speaking frankly with positive politeness. This is in line with the opinion of Brown and Levinson (in Wijayana, 2009: 135-136) which states that the sub- strategies in the strategy of speaking frankly with positive politeness include (1) paying attention to what the interlocutor needs, (2) using markers group solidarity and fostering an optimistic attitude, (3) involving speech partners in speaker activities, (4) giving praise to speech partners, (5) offering something, (6) avoiding such incompatibility, and (7) being funny [11]. The speech above is included in this strategy because it is a form of the sub- strategy based on expert opinion, namely giving praise to the speech partner.

\subsubsection{Strategy to Speak Frankly with Negative Politeness}

The strategy of speaking frankly with negative politeness was found as many as 9 utterances in the learning process. As with the previous narrative strategy, the teacher's role here is the same. What distinguishes it is only the function of the teacher using this speech strategy. The teacher tries to reduce or minimize certain burdens as something that cannot be avoided by students. The following are the findings of the strategy research, telling frankly with negative politeness.

(3) Oh yeah, sorry. Task six huh. Task five just sums up. (T99)

The above speech is a form of praising speech act with a strategy of speaking frankly with negative politeness. This is in line with the opinion of Brown and Levinson (in Wijayana, 2009: 135-136) which states that the substrategy in the strategy of telling frankly with negative politeness includes (1) indirect expression, (2) use of hedges or interrogative sentences, (3) being pessimistic, (4) not burdening the speech partner, (5) using the passive form, (6) apologizing, (7) using the plural form. The above speech is included in the strategy of speaking frankly with negative politeness, because the speech is classified as a sub strategy for expressions of apology.

\subsubsection{Vaguely Spoken Strategy}

The strategy of speaking candidly is a strategy that is more likely to be in the form of expressive speech acts of criticism and blame. In the learning process, only 4 utterances were found. The obscure speech strategy is an indirect strategy by letting the speech partner decide how to interpret the speaker's speech. This storytelling strategy is used by the teacher at least because a teacher has the role of optimizing learning activities. The speech strategies the teacher uses, the more difficult it will be for students to grasp the material and 
information conveyed by the teacher. therefore, the teacher tries to avoid this narrative strategy. As in the findings of the following research results.

(4) How come a lot of silence, even though you know! Or don't you know at all? This is your elementary school student lesson! This is also the same answer as the person appears! (T165)

In the above speech, it is a form of critical speech act with a vague strategy of speaking. The teacher criticizes the students who are only silent during the learning process, and the criticism given by the teacher is in the form of criticism that contains responses that are not clear about the meaning of the speech. So that students who want to answer will feel hesitant to answer it.

\section{CONCLUSIONS AND SUGGESTIONS}

Based on the findings of the research obtained along with the discussion, the conclusions of the research regarding the form of expressive speech acts and the teacher's speaking strategy in Indonesian class XI learning at SMA 1 Luhak Nan Duo are described as follows. First, there are five forms of expressive speech acts of teachers in Indonesian language learning at SMA N 1 Luhak Nan Duo, namely (1) expressive speech acts praising, (2) expressive speech acts saying thank you, (3) speech acts expressive criticism, (4) expressive speech act of blaming, and (5) expressive speech act of apologizing. Second, there are four types of speaking strategies used by the teacher in learning Indonesian language at SMA 1 Luhak Nan Duo, namely (1) the strategy to speak frankly without further ado,

Through the research results and conclusions, there are several suggestions that can be described as follows. First, Indonesian teachers are expected to be able to use various forms of expressive speech acts so that they are more varied in speaking and in the delivery of material to students during the learning process and so that they can become examples of language politeness by students. Second, students are expected to be polite in responding to every speech spoken by the teacher, and students are also expected to be more competitive and participate in the teaching and learning process. Kegita, for enthusiasts and prospective Indonesian language teachers, it is hoped that they can know and understand how to speak well, choosing the form of speech acts and the right strategy in communicating.

\section{REFERENCES}

[1] Yule, G. 2006. Pragmatics. Yogyakarta: Student Library.
[2] Chaer, Abdul. 2010. Early Introduction Sociolinguistics. Jakarta: Rineka Cipta.

[3] Abdurrahman. 2006. "Pragmatics: Basic Concepts of Understanding the Context of Speech". Lingual Journal of Language and Literature. (1) 1693 4725, 117-133. Chaer,

[4] Rahardi, Aristo. 2003. Learning Media. Jakarta: Ministry of National Education.

[5] Rustono. 1999. Principles of Pragmatics. Semarang: CV of the IKIP Semarang Press.

[6] Halid, et al. 2011. "Strategies for Speaking Indonesian Language Teachers in the Learning Process in Islamic Junior High School Ar-Risalah Padang". Lingua Didaktika. 5 (1), 1-17.

[7] Syahrul, R. 2008. Pragmatics of Language Politeness: Uncovering the Phenomenon of Indonesian Language Teachers and Students, Padang: UNP Press.

[8] Sugiyono. 2014. Quantitative Research Methods, Qualitative, and R \& D. Bandung: Alfabeta.

[9] Sari, FDP. 2012. "Speech Actions and Expressive Speech Functions in Upbeat Nite Events on Metro

[10] Rahardi, Aristo. 2003. Learning Media. Jakarta: Ministry of National Education.

[11] Wijayana, I Dewa Putu and Muhammad Rohmadi. 2009. Pragmatic Discourse Analysis: Theory and Analysis Study. Surakarta: Yuma Pustaka.

[12] TV: A Pragmatic Study". Scriptorium. 1 (2), $1-14$. 